\title{
北上川中流域における黒沢尻火山灰の層序・分布と 強磁性鉱物の化学組成
}

\author{
井上克弘 ${ }^{2)}$.小㳑敦 ${ }^{21}$
}

\section{Stratigraphy, Distribution, Mineralogy, and Geochemistry of the Kurosawajiri Volcanic Ash in the Middle Kitakami River Basin, Northeastern Japan ${ }^{1)}$}

\author{
Katsuhiro INOuE $^{2)}$ and Atsushi KonUma ${ }^{2)}$
}

The Murasakino (or Isawa) Terrace developed in the middle Kitakami River basin, northeastern Japan is covered with the Kurosawajiri Volcanic Ash (KVA). Its marker bed, the Murasakino Pumice is divided into two pumice beds different in an eruptive cycle, namely the Kitakami Pumice and the Isawa Pumice. The Isawa Pumice is older than the Kitakami Pumice. The Kitakami Pumice bed is composed of three fall units, MKP-I, II, and III, and the Isawa Pumice bed is composed of four fall units, MIP and three solidified volcanic ash beds (SVA-1, 2, and 3). Among them, MKP-II and MIP are distributed extensively in the northeastern and southeastern directions from the Mt. Yakeishi, respectively. SVA overlain by MIP is distributed in the eastern and southeastern directions from Mt. Yakeishi and the distribution is limited in the narrow area.

The bedding plane between the Murasakino Pumice beds (MKP-II, MIP) and volcanic ash layers of the KVA formation is often disturbed irregularly. This disturbance would be attributed to cryoturbation (involution) in the glacial age. Judging from the stratigraphical relationships between the Murasakino Pumice beds and the terrace surfaces, and the red weathering crusts, the fossil periglacial phenomena observed on MKP-II and MIP, and the degree of weathering in ash layers of the KVA formation, the Murasakino Pumice beds would be erupted in the Alt-Würm subglacial age (about 40,000 70,000 years ago).

The heavy mineral (s.g. $>2.90$ ) content is about $50 \sim 90 \%$ for MKP-I $\sim$ III, and about $20 \sim$ $60 \%$ for MIP and SVA-1 3, respectively. The heavy mineral composition is in the order of magnetite $\geq$ hypersthene $>$ augite for MKP-I $\sim$ III, and hypersthene $\geq$ magnetite $>$ augite $>$ hornblende for MIP and SVA-1 3, respectively. MIP and SVA-1 3 contain a comparable amount of quartz, but MKP-II contains it scarcely.

Chemical components, $\mathrm{Fe}, \mathrm{Ti}, \mathrm{Mn}, \mathrm{V}$, and $\mathrm{Zn}$, of ferromagnetic minerals purified from tephra deposits were determined. On the basis of the relationships between $\mathrm{V}-\mathrm{Zn}$ belt and the content of $\mathrm{SiO}_{2}$ of tephra deposits (Shoji et al., 1975), it is estimated that MKP-I III and SVA-1 23 are andesitic, and MIP is dacitic in rock type. The greater part of tephra deposits composing the KVA formation is erupted from the Yakeishi Volcano, and is andesitic to dacitic in rock type. However, the upper ash layers of the KVA formation may be contaminated with rhyolitic ashes, probably erupted from the Kurikoma Volcano.

1) 1980 年 2 月 14 日受付

本研究の概要は 1980 年 4 月の日本土壤肥料学会大会に打いて発表した。また本研究の経費の一部に昭和 54 年度交部省科学研究費 (一般研究 $\mathrm{C}$ ) を使用した。

2) 岩手大学農学部土壤学教室 Laboratory of Soil Science, Faculty of Agriculture, Iwate University. 


\section{I. は じめに}

東北地方には第四紀火山が多数存在している。このう ち十和田火山（中川ら，1972; 大池，1972）, 秋田駒ヶ 岳火山（INOUE，1980）㧊よび岩手火山と秋田焼山火山 (INOUE and YosHIDA, 1980)については更新世〜完新世 テフラの層序・分布・編年が汪ぼ明らかにされている が，その他の火山についてはまだ不明の点が多い. 北上 川中流沿岸には段丘がよく発達している.中川ら (1963) は火山灰編年学的手法を用いて本地域の段丘を花巻一金 ヶ崎間では高位のものより西根段丘，村崎野段丘，金ヶ 崎段丘に，委た金ヶ崎以南では同様に一首坂段丘，胆沢 段丘，水沢段丘に区分している．ここで西根（一首圾） 段丘，村崎野（胆沢）段丘および金ヶ崎（水沢）段丘を 中川ら (1963) はそれぞれ関東地方に発達する多摩段丘, 下末吉段丘および立川・武蔵野段丘（関東ローム研究グ ループ，1965)に対比している.

北上川中流域に分布する火山灰は段丘との関連より, 新期のものより黑沢尼火山灰, 前沢火山灰和よび一首坂 火山灰に区分される (中川ら, 1963). このらち黒沢尻火 山灰は村崎野段丘执よび胆沢段丘群のらち福原段丘を整 合的に覆っている。おたこれより高位の段丘では前沢 火山灰をほほ整合的に覆っている. 中川ら (1963) はこ れらテフラの起源を栗駒山执よび焼石岳と推定してい る.

黒沢屑火山灰の主部は黄橙色粗粒の村崎野浮石で上方 に褐色火山灰を伴っている. 本浮石層は北上市付近に 広く分布することから「北上浮石」とも呼ばれている (WAdA and Matsubara, 1968 ; Yoshinaga et al., 1973).

塩入（1935）は岩手県飯豊町藤沢の風化した安山岩質 浮石（村崎野浮石に相当）層中にゲル状皮膜物質を発見 し，コロイド化学的研究より本物質がアロフェンである と推定した. その後, 本浮石層中のゲル状物質は管野ら (1960)によって結晶度の極めて低いモンモリロナイト様
鉱物，アロフェン打よび遊離の鉄・アルミニウム化合物 からなると報告されたが，これは YoshinaGA and AoMINE (1962) によって発見された新種珪酸塩鉱物イモゴ ライトでめることが明らかにされた（MIYAUCHI and Aomine, 1966).

WADA and MAtsubara(1968) は本浮石層に叔けるア ロフェン，イモゴライト，ギブサイトの産状を調べ，ア ロフェンとイモゴライトは浮石粒子の風化に伴い平行的 に生成されるが，ギブサイトはこれらと独立に生成され ることを示した。また YoshinaGA et al. (1973)は更新 世段丘粘土層の上位にある村崎野浮石層の浮石粒子間に ギブサイトとハロイサイトが異常に集積している事例を 見い出してその生成機構を明らかにした。

近年，土壤学分野ではアロフェン，イモゴライトに関 する研究が急速に進展したが，村崎野浮石層中のゲル状 皮膜物質と浮石粒子はイモゴライト，アロフェンの構造 や機能に関する研究に標準試料としてしばしば使用され ている (WADA and Henmi, 1972 ; Henmi and WADA, 1974 ; CRADWICK et al., 1972 ; WADA and WADA, 1977).

小野・庄子 (1978) は岩手県北上市付近の火山扊土壤 の生成に関する研究に执いてテフラ中の強磁性鉱物の化 学組成がテフラの識別に有效であることを明らかにし た.すなわら, SHOJi et al. (1975) がテフラの岩質判定 に用いた $\mathrm{V} /(\mathrm{Fe}+\mathrm{Ti})-\mathrm{Zn} /(\mathrm{Fe}+\mathrm{Ti})$ ベルトと考古学 的資料を基礎にして村崎野浮石層までのテフラは上部よ り $1,000 \sim 5,000$ 年と推定される石英安山岩質の累積 火山灰，10,000 数万年前之推定される安山岩質の累積 性火山扊末よび数万年ないしそれ以上の安山岩質の火山 灰と村崎野浮石層よりなっていると推論した.

上記のように黒沢㞔火山灰について地理学的・粘土鉱 物学的にはかなり詳細に研究されているが，その層序・ 分布などに関してはまだ明らかにされていない。そこで 村崎野浮石層を主な研究対象とし，黒沢尻火山灭の層 序・分布・起源・噴出年代扰よびその鉱物学的性質と強

Fig. 1 Map showing Survey Area, Sectional and Sampling Sites, and the Thickness Gontour Map of the Marker Beds.

A; Ishidoriya, B; Hanamaki, G; Kitakami, D; Kanagasaki, E; Mizusawa, F; Maesawa, G; Hiraizumi, H; Ichinoseki, I; Tsuchizawa, J; Esashi, K; Higashiyama, L; Ohazama, M; Miyamori, N; Daito, O; Tohno, P; Sumita, Q; Yamada, R; Kamaishi, S; Ohfunato, T; Rikuzentakata, a; Mt. Yakeishi, b; Mt. Kurikoma,' c; Mt. Tabashine, d; Mt. Ahara, e; Mt. Monomi, f; Mt. Hayachine, g; Mt. Yakushi, h; Mt. Hitotsuishi, i; Mt. Ishigami, j; Mt. Rokkoushi, k; Mt. Goyoh, 1; Mt. Kanokura, m; R. Kitakami, n; R. Toyosawa, o; R. Waga, p; R. Isawa, q; R. Koromo, r; R. Iwai, s; R. Sarugaishi, t; R. Satetsu, u; R. Hei, v; R. Ohtsuchi, w; R. Ohmata, Numbers; sectional and sampling sites, Dotted line; 1,000 m contour line. 


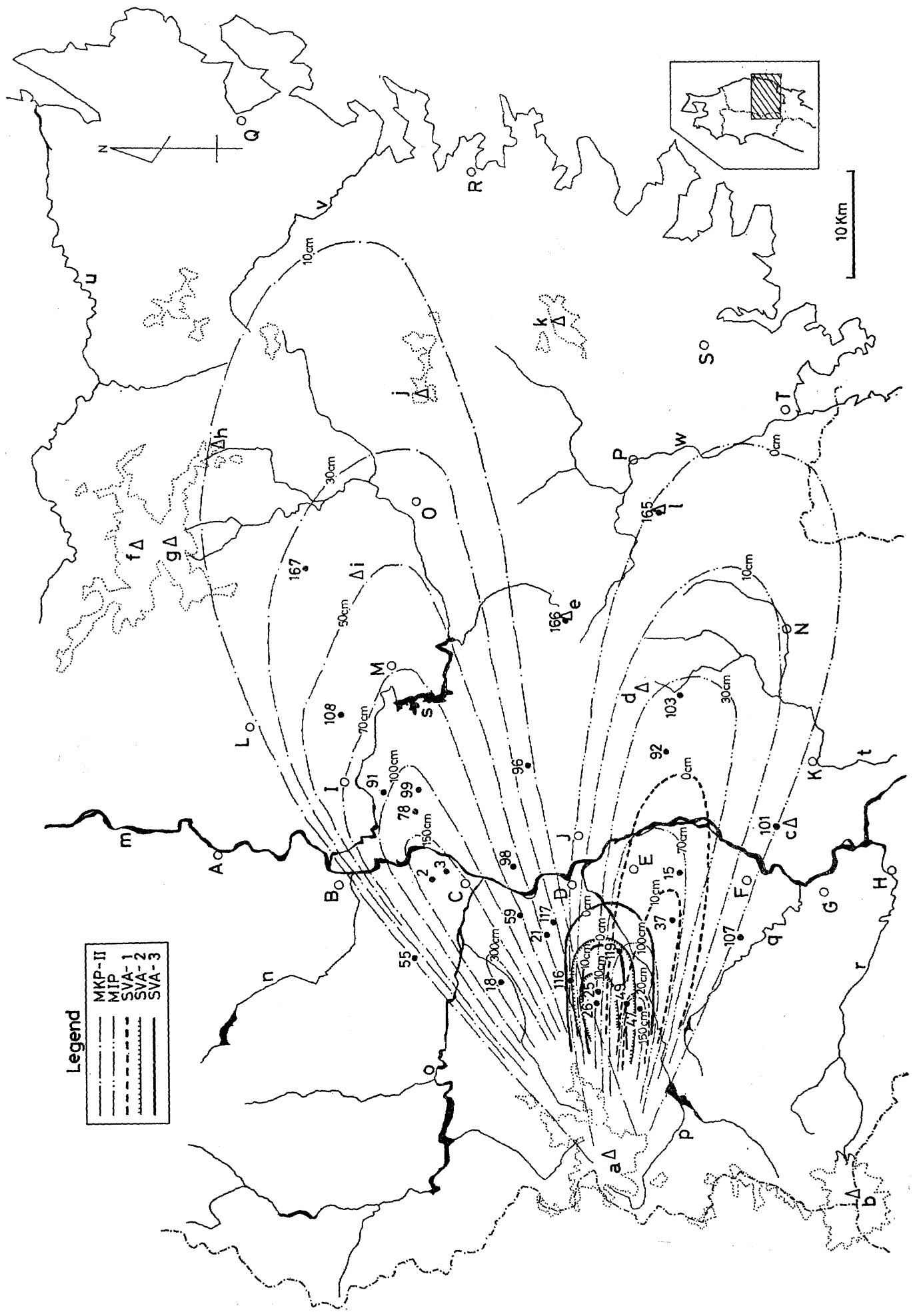


磁性鉱物の化学組成からテフラの岩質を明らか飞するこ とを本研究の主目的とする。

\section{II. 試料と実験方法}

（1）調查地域 北上川中流沿岸のらち花巻一花泉間 を主な調查地域とし，西側の奥羽山脈から東側の北上山 地南部にか約 170 地点について層序学的調查を行った (Fig. 1). 本地域に注奥羽山脈に栗駒山 $(1627 \mathrm{~m})$ 之嵝 石岳 $(1548 \mathrm{~m})$ の第四紀火山があり両火山とも更新世中 期〜後期にか沙て活動したと考兄られる．完新世に入っ てからの両火山の活動に関しては十分な資料はないが， 栗駒山は江戸時代以降しばしば小噴火をしておうり, 1944 年の小噴火により昭和湖を形成した（村山，1978）。一 方，焼石岳の火山活動に関しては全く資料がない。

（2）供試試料 調查地域中の約 170 地点に括祆る層 序学的調查の際に 14 地点より 39 点の火山灰と浮石を採 集し，一次鉱物組成抒よび強磁性鉱物の化学組成分析の ための試料とした.

(3) 一次鉱物組成 村崎野浮石層扮よび調查地点 No. 47 の各層序より採集したテフラについて有機物を $\mathrm{H}_{2} \mathrm{O}_{2}$ で分解後, 超音波処理 $(19.5 \mathrm{KHz}, 200 \mathrm{~W}, 10$ 分 間）した. 脱鉄処理 (MEHRA and JACKSON, 1960) 後粘 土部分を廃棄し, 残部を乾燥後節別し $1 / 8 \sim 1 / 16 \mathrm{~mm}$ 画 分を得た. 本画分をブロモホルム重液 (s. g. 2.90) で軽 鉱物画分と重鉱物画分に分画した. 重鉱物画分について はその一部をカナダバルサム中に封じ込み，偏光顕微鏡 下で約 600 粒の重鉱物を鑑定した。 なた軽鉱物はX線回 折と偏光顕微鏡により鑑定し, 軽鉱物中の 石英含量は $\mathrm{CaF}_{2}$ を内部標準物質としX線回折（粉末法）により定 量した（長友・斎藤，1971).

\section{（4）強磁性鉱物の分離・精製と化学組成の分析法}

浮石特よび火山灰より棒磁石により採集した強磁性鉱物 をメノウ乳鉢中で粉砕し, 水中での選別により精製した. 本操作は数回繰り返した. 精製した強磁性鉱物 $100 \mathrm{mg}$ を王水一フッ化水素酸で分解し, 分解液について全 $\mathrm{Fe}$, $\mathrm{Ti}, \mathrm{Mn}, \mathrm{V}$ 抢よび $\mathrm{Zn}$ を定量した・全 $\mathrm{Fe}$ は Oーフェ ナントロリン法, Ti はタイロン法, V は BPA 法によ

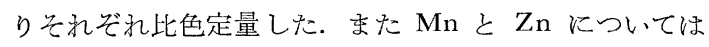
原子吸光法によりそれぞれ定量した（庄子ら，1974； Sнојг et al., 1975).

\section{III. 結果および考察}

\section{(1) 黒沢尻火山灰の層序}

黒沢尻火山灰の示標層である村崎野浮石層は北上市付
近で厚く南下寸るにつれその層厚を減少させ金ヶ崎町付 沂で薄失する．しかし水沢以南では再び浮石の層厚は厚 くなる、したがって，北上市付近の浮石層と水沢市付近 の浮石層は層序和よび分布が異なると予想される。また 黒沢㞔火山灰は数種の降下単位より構成されている。 そ こでまずこれら降下単位の層序学的関係を検討した.

村崎野浮石層のらち焼石岳の北東方向に厚く分布する 粗粒質浮石を北上市小鳥崎 (No. 3) を模式地として北上 浮石層々呼ぶ。また焼石岳南東の胆沢扇状地に厚く分布 する粗粒質浮石を胆沢町十文字を模式地として胆沢浮石 層々命名する。模式地に沶いて北上浮石層と胆沢浮石層 の層厚はそれぞれ $160 \mathrm{~cm}, 90 \mathrm{~cm}$ である.両浮石層は ともに数種の降下単位より構成されている。すなわち, 金分㥓町西根付近の丘陵地 (No. 117) では北上浮石層は 層厚 $2 \mathrm{~cm}$ の灰白色粘土層をはさんで上部のやや固結し た細粒質浮石と下部の粗粒質浮石層に区分され，第三 紀層の風化層を覆っている. 前者を MKP-1, 後者を MKP-II，両者の間の灰白色粘土層を Gb-1 と呼ぶ. ま た相去町和田付近の第三紀層丘陵地 (No. 59) も北上浮 石層によって覆われているが，これは MPK-II と下位 の弱く固結した細粒質浮石層（MKP-III呼ぶ）に区分 される.

一方，金ヶ崎町大沢付近 (No. 25) では層厚 $70 \mathrm{~cm}$ の胆沢浮石 (MIP と呼ぶ, 最大粒径 $10 \mathrm{~cm}$ ) の上部に径 $3 \sim 8 \mathrm{~mm}$ の灰白色結核に富む弱固結火山灰 ( $\mathrm{Gb}-2$ 之 呼ぶ）が，また下部には 2 層の固結火山灰が㘯る。上部 の灰黒〜青黑色砂状火山灰は固結し非常に堅いが，下部 の中粒質浮石と火山䃋に富む火山灰層の固結度は中程度 である. 金ヶ崎町細野付近 (No. 49) では MIP と砂状 固結火山灰層の間にさらにもら一層の灰白色の中粒質浮

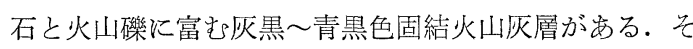
こで MIP の下部にある 3 層の固結火山灰層を金ヶ崎固 結火山灰と命名し，上より SVA-1，SVA-2 特よび SVA-3 と呼ぶ. さら飞金ヶ崎町女夫坂付近 (No. 47) では MIP と MKP-II の間に層厚 $55 \mathrm{~cm}$ の重粘な褐 色火山灰層をはさんでいる. したがって MIP と MKP$\mathrm{I}$ IIIの噴出期は異なり，しばらくの時間的間隙がある と考えられる。

な拈，X線回折によれば Gb-1 と Gb-2 以含まれる灰 白色小結核はギブサイトを主成分としている.

各降下単位の層序学的関係を模式的に示すと Fig. 2 の上らになる。すなわち腐植に富む黒色火山灰層と褐色 火山灰層の下に MKP-I，II抒よびII より構成される北 上浮石層がある。そして MKP-I と MKP-IIの間には 


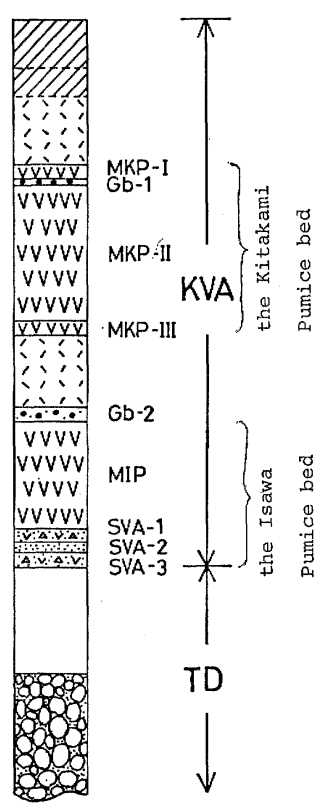

Fig. 2 Schematic Stratigraphy of the Kurosawajiri Volcanic Ash. KVA; the Kurosawajiri Volcanic Ash, TD; Terrace Deposits. For legend see Fig. 3.

ギブサイト質粘土薄層 (Gb-1) をはさむ.MKP-IIは層 厚が厭く浮石粒子間にはしばしばゲル状皮膜（イモゴラ イト)を含んでいる。またハロイサイト，ギブサイト質 の褐色粘土が MKP - II の上部浮石粒子間を充填してい るのがしばしば観察される。

MKP-I〜IIIの下部には重粘な褐色火山灰層をはさん でMIP と 3つの降下単位からなる固結火山灰層 (SVA1〜3) より構成される胆沢浮石層がある. MIP も MKP-II と同様に粗粒質の浮石粒子間はしばしば無色〜 淡黄色のゲル状皮膜に富んでいるが，浮石粒子間がすっ かり褐色粘土で充垍されている場合も観察される.これ は上部の火山灰層からの粘土の移動・沈積によると考え られる.MIP の上部にはギブサイト質結核に富む弱く固 結した粗粒火山灰層がある。

これらの生成・充塤には透水性や微地形など風化環境 の違いが関与していると思われる.

北上市付近に 発達する村崎野段丘は北上浮石層に上 り，また水沢市付近に発達する胆沢段丘群のららの福原 段丘は胆沢浮石層によって整合に覆われている。また， より高位の段丘や丘陵地では両浮石層が直接前沢火山灰 層を注ぼ整合に覆っている. しかし焼不岳東麓の丘陵地 では北上浮石層と火山灰層は法とんど削袔されている場
合が多く，本研究に和いて MKP-II と MIP の両浮石 層を有する断面は No. 47 地点のみである.このことは 降灰後堆積物の削剥と侵食が著しく進行したことを示唆 している.

\section{（2）調查地域における柱状図例}

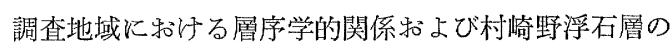
層厚变化を示すため調查地点約 170 箇所より 20 地点を 選び，その柱状図を Fig. 3 に示す. な特，層序学的調 查にあたっては経済企画庁怙よび岩手県による国土調查 （1963〜1975）を参照した。

村崎野浮石層は村崎野段丘 (No. $3,18,55,98$ ), 胆沢 段丘群福原段丘 (No. 15, 119)，第三紀層風化物 (No. $59,117)$ 和よび赤色風化殼（No. 78）を直接覆ってい る.また西根 (一首坂) 段丘 (No. 21，107)，焼石岳 東麓の 丘陵地 (No. 25，47), 江刺市青篠付近の 丘陵地 (No. 96) 抢よび束稲山北麓の山毛欅峠（No. 101）では 前沢火山灰を覆っている. さらに北上山地では東和町平 山 (No. 108) の扇状地性堆積物や蓬来山北方の山麓緩斜 面 (No. 103), 物見山（種山, No. 166) 拉よび叶倉山 (No. 165) の古生層風化物を覆っている. 以下，Fig. 3 に示した柱状図のらち主なものについて説明する。

焼石岳北東約 $20 \mathrm{~km}$ に位置する和賀郡和賀町岩崎新 田上夏油付近 (No. 18) は村崎野段丘堆積物を約 $3 \mathrm{~m}$ の MKP-II が覆っている.本浮石層はさらに径 $3 \mathrm{~cm}$ 以下 の円礫と浮石を含を層厚 $110 \mathrm{~cm}$ の茶褐色〜褐色凝灰質 層执よび層厚約 $170 \mathrm{~cm}$ の瘤木䃯層 (KG と略記) と花

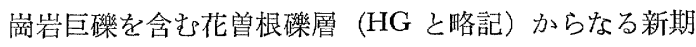
扇状地性䃯層によって覆われている (中川ら，1963).

KG と MKP-II の間にはさまれている堆積物は降下物 ではなく二次堆積物と考えられる.MKP-II の最大粒径 は約 $20 \mathrm{~cm}$ で全体的に粗粒質である.

焼石岳北東約 $30 \mathrm{~km}$ の北上市小鳥崎 (No. 3) では飯 豊礫層と灰白色粘土層よりなる厚い村崎野段丘堆積物の 上を層厚 $160 \mathrm{~cm}$ の $\mathrm{MKP}-$ II と $115 \mathrm{~cm}$ の褐色〜黒褐 色火山灰が覆っている. 浮石の最大粒径は $5 \mathrm{~cm}$ で浮石 粒子間にイモゴライトゲルが認められる.

焼石岳北東約 $36 \mathrm{~km}$ の東和町宮田 (No. 78) では層 厚約 $120 \mathrm{~cm}$ の MKP-II が約 $2 \mathrm{~cm}$ の灰白色粘土層を はさんで厚いチョコレート色の赤色風化殼を覆ってい る.浮石層は $50 \mathrm{~cm}$ の褐色火山灰で覆われ, 浮石層の下 部 $35 \mathrm{~cm}$ は粒子間が褐色の粘土によって充填されてい る. 浮石の最大粒径は約 $3 \mathrm{~cm}$ である.

焼石岳南東約 $20 \mathrm{~km}$ の胆沢郡金ヶ崎町高梨付近 (No.119) は胆沢鿬層（中川ら, 1963） と灭白色～灰黄橙 

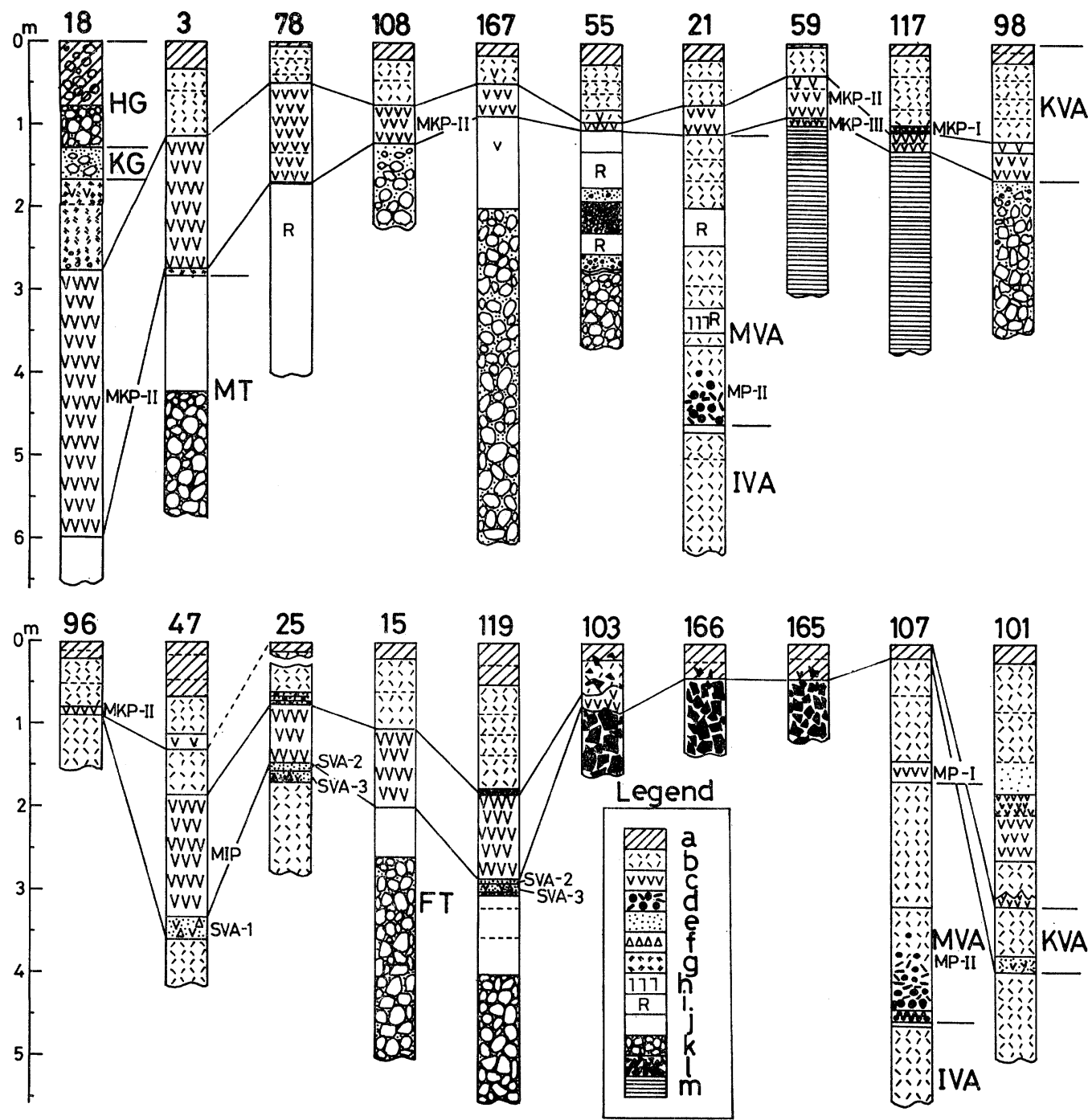

Fig. 3 Representative and Schematic Columnar Sections.

HG; Hanasone Gravel, KG; Kobuki Gravel, MT; Murasakino Terrace, FT; Isawa (Fukuhara) Terrace, MVA; Maesawa Volcanic Ash, IVA; Isshuzaka Volcanic Ash, a; Humus layer, b; Ash, c; Pumice, d; Halloysite Nodule and Halloysite-Gibbsite Concretion, e; Solidified Volcanic Ash or Coarse Grained Volcanic Ash, f; Lapilli, g; Secondary Deposits, h; Crack, i; Red Weathering Grust or the Red-Weathered Volcanic Ash, j; Clay Deposits, k; Gravel, 1; Paleozoic Strata, m; Tertiary. For legend see Figs. 1 and 2.

色粘土層からなる胆沢段丘堆積物を層厚 $120 \mathrm{~cm} \mathrm{の}$ MIP と SVA からなる胆沢浮石層が整合に覆ってい る・これはさらに層厚約 $2 \mathrm{~m}$ の褐色〜黑色火山灰によっ て覆われている。

六原扇状地上の西根段丘（No. 21） と胆沢扇状地上の
一首坂段丘 (No. 107) は黒沢层火山质層の下部に前沢火 山灰層之一首坂火山灰層を有する。一首坂段丘上の前沢 火山灰層中には 2 層の前沢浮石層が存在する.上部のも のを MP-I，下部のものを MP-II と呼ぶ. MP-II は風化が非常に進行し浮石の形態を法とんどとどめてい 
ないが，ハロイサイト，ギブサイトに富も球状団塊や棒 状の Pedotubule 様結核が非常に多く重要な示標層とな っている(井上・吉田 1976)。 また No. 21 の断面の前 沢火山灰層中には 2 層の赤色風化を受けた火山灰層が ある。

焼石岳南東約 $35 \mathrm{~km}$ の束稲山北麓山毛㰒峠 (No. 101)では黒沢居火山灰層の上部に 2 層の浮石層を有する 火山灰層が累積している. これら浮石層は前沢町以南に 分布し，石英粒子にすこぶる富み，岩質は石英安山岩質 〜流紋岩質である (井上・未発表)。したがって,これは 焼石火山以外の火山（抢そらく栗駒山）起源の噴出物で ある可能性が強い。

焼石岳東方約 $45 \mathrm{~km}$ の蓬来山付近にある立石東麓緩 斜面露頭 (No. 103) では粘板岩岩片に富む暗褐色古生層 風化物を MIP が攪乱された形で覆い，これはさらに径 $25 \mathrm{~cm}$ 以下の輝緑凝死岩質角碩に富む褐色火山灭によっ て覆わ机る。焼石岳東〜南東約 $50 \sim 60 \mathrm{~km}$ にある物見 山（種山）山頂付近 (No. 166) と叶倉山山頂付近 (No. 165)ではいずれも輝緑凝灰岩あるいは泥岩よりなる古生 層基岩を腐植に富む黑色火山灰が覆っている，黒色火山 灰は小角䃋を含み，No. 165 では褐色の小浮石粒も含ん でいる. No. 103, 165 执よび 166 断面に执汁る火山灰層 中への小角礫の混入は降灰後火山灰がンリフラクション 等最終水期に和忷る周氷河作用を受けたためと思われ る.

な报，燒石岳北東約 $63 \mathrm{~km}$ にある遠野市大洞牧場 (No. 167) の柱状図は国土調査（1971）上り引用した. 本柱状図中にみられる浮石層は後述のように浮石の層 厚, 分布から MKP-II であると考劣られる。

\section{（3）村崎野浮石の分布之起源}

村崎野浮石層は噴出方向特よび eruptive cycle の異 なる北上浮石層と胆沢浮石層に区別される.北上川中流 沿岸から北上山地南部にかけての約 170 箇所に和ける 層序学的調查に基づき, MKP-II, MIP 特よび SVA1，2，3 についてそ水らの分布と等厚線を Fig. 1 亿示 于.

MKP-II は夏油川流域で最も厚く, $3 \mathrm{~m}$ 以上の層厚を 示すが，北上市付近で $150 \sim 180 \mathrm{~cm}$, 相去町, 村崎野, 東和町駒籠で $100 \sim 130 \mathrm{~cm}$, 和賀郡和賀町北藤根, 東和 町土沢, 北上市下口内で $70 \sim 90 \mathrm{~cm}$, 東和町平山, 花巻 市高松, 江剌市柏原で約 $50 \mathrm{~cm}$, 遠野市大洞, 花巻市山 の神，金ヶ崎町西根で約 $30 \mathrm{~cm}$ と層厚を減ずる。

MKP-II は北上市より北方にいくにつれて急激にそ の層厚を減少させ和賀郡後藤㘿の下，花巻市以北で薄失
する.また南方向への浮石の層厚変化は比較的ゆるやか であり, 江刺市青篠以南で消失する.MKP-II の分布の 主軸は烧石岳と北上市をむすぶ線上にあり，ほぼ棈円形 状に焼石岳の北東方向に分布しているが，浮石噴出後の 風向の変化のためか東和町付近から北上山地南部にかけ てはやや東方に流された形状を示している (Fig. 1).

一方, MIP は焼石岳の東南東方向に分布し, 胆沢扇状 地段丘の大部分を覆っている.MIP の最大層厚は胆沢扇 状地扇頂付近の金夕崎町永栄で約 $170 \mathrm{~cm}$ であり, 東南 東方向に先の層厚を漸減させる。すなわち, 金ヶ崎町高 梨, 胆沢町供養塚で約 $100 \mathrm{~cm}$, 胆沢扇状地扇端の折館付 近，金ヶ崎町大谷地で $70 \sim 90 \mathrm{~cm}$, 江剌市大平, 胆沢町 横屋, 金ヶ崎町大沢付近で $40 \sim 60 \mathrm{~cm}$, 大東町鳥海, 胆沢町上狼志田，金ヶ崎町潤沢で $20 \sim 30 \mathrm{~cm}$ である。 MIP む南北方向には急激にその層厚を減少させている. その北限は蹱石岳一江剌一叶倉山を結ぶ線上にあり，南 限は焼石岳一束稲山を結ぶ線上にある.MIP は焼石岳と 胆沢町供養塚を結ぶ延長線を主軸とし，ほぼ棈円形状に 分布している (Fig. 1). 住田町叶倉山の山頂付近 (No. 165) には前述のと和り火山灰中に微量の小浮石粒子を混 在するが，この浮石は MIP の可能性が強い.

焼石岳東方の物見山（種山）山頂付近 (No. 166) や大 森山西麓の山大畑には $40 \sim 80 \mathrm{~cm}$ の角礫を含む黒色火 山死が輝緑凝灭岩質の古生層基岩を覆らが, 浮石の存在 は認められない。

MKP-II 和よび MIP はその分布域や浮石の層厚変 化からみて噴火の規模は前者の方がやや大きいが，いず れも焼石火山を質出源としている。 な和 MKP-I は金 ヶ崎町西根付近で，また MKP-III は相去町和田付近で 確認されたが，いずれも調查地点の不足からその分布域 は図示できなかった，しかし，いずれも層厚は薄く， MKP-II と注济同一方向に狭い範囲で分布するものと 思われる。

また，MIP の下部にある金崎固結火山灰層 (SVA1〜3) はいずれも焼石岳を噴出源とし, SVA-1 は MIP とほぽ同一方向に，また SVA-2 と SVA-3 は燒石岳の 東方に比較的狭い地域に分布している。

上記のと括り村崎野浮石層は噴出方向执よび eruptive cycle の異なる 2 つの浮石層より構成され，1 つは焼 石岳の北東力向に, 他の 1 つは焼石岳の東南東方向に分 布している．村崎野浮石層が分布の異なる 2 層の浮石層 に区分される可能性については本浮石濖の命名者である 中川ら·(1963) によってすでに指摘されている.すなわ ち中川らは夏油川流域に蛞いて若い扇状地性䃯層下に埋 
没した浮石膡が上下に細分され，重鉱物分析より夏油川 流域に打けるこの浮石層下半は北上市付近のものに，上 半は胆沢川北岸平林付近のものにそれぞれ類似すると報 告している.

この結果は最初に北上市付近の浮石が，ついで平林付 近の浮石の噴出があり，その噴出時期は葟ぼ同時期であ ると推論させる。しかし，後述のように夏油川流域の MKP-II の上部にある 円砅と浮石を含む火山灰質凝灰 層は角閃石を含む点で MIP に重鉱物組成が類似する が，強磁性鉱物の化学組成特よび岩質は明らかに MIP とは異なっている (Table 3，Fig. 5 参照). したがっ て, Fig. 2 の層序に示すように浮石の噴出は MIP が最 初であり，しばらくの時間的間隙を括いて MKP-II の 噴出があったと考えられる。

\section{（4）村崎野浮石の噴出時期}

東和町南成島小倉山付近の丘陵地（No. 91）にある露 頭は Fig. 4 に示したように赤色風化殼を径 $10 \mathrm{~cm}$ 以下 の岩片に富む新第三紀安山岩質のシルト質凝灰岩層が約 1 2mの嬮さで覆い，北東方向に $10^{\circ}$ 傾斜している. シ ルト質凝灰岩層は径 $3 \mathrm{~cm}$ 以下の $\mathrm{MKP}-$ II (層厚 $85 \mathrm{~cm}$ ) により覆われ，さらに浮石層を径 $2 \sim 18 \mathrm{~cm}$ の岩片执よ び亜角碟を含む褐色火山灰（層厚 $145 \mathrm{~cm}$ ) が覆ってい る. MKP-II と上部の火山兏層の境界部分は不規則で著 しく攪乱されている．同様な村崎野浮石層の攪乱は胆沢 段丘上の水沢市見分森自然公園付近をはじめ各地で観察 された。しかし，村崎野浮石層の攪乱は層厚が厚い場合 浮石層の上部にの及観察され，浮石層全体に末では及ん でいない.

このような浮石層の灚乱は寒冷気候下にお汀る涷結融 解現象に基づく周氷河現象の一つであるクリオターベー ション(インボリューション)であると推定される. 北上 川上流域の岩手山東麓掞よび北上山地外山高原で渋民 火山灰層中にしばしばスコリア層のインボリューション

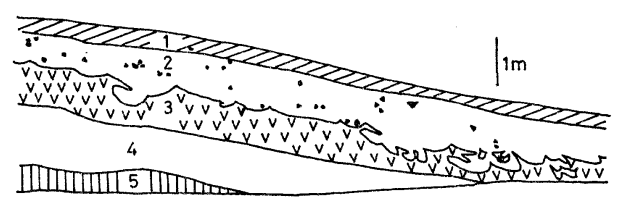

Fig. 4 Outcrop Showing Cryoturbation in the Section No. 91.

1; Humus Layer, 2; Ash Layer Containing Rock Fragments, 3; MKP-II, 4; Tertiary Deposits, 5; Red Weathering Crust. For legend see Fig. 1.
が観察され (井上ら，1977 ; 遠藤，1977 ; 井上，1979), この層理の攪乱は火山灰層序， ${ }^{14} \mathrm{C}$ 年代扣よび花粉分析 から約 20,000 30,000y. B. P. 飞打沙万周水河現象と 考えられている.さらに井上 (1979) は北上山地姫神山 に拉ける岩塊流の形成時期として上記寒冷期のほかに $34,000 y$. B. P. 以前とさらに古い氷期も認めている.

鈴木（1962）は最終水期に和ける低位周氷河現象の南 限を盛岡一久慈線に設定したが，若生（1964）は南限が 福島県白河付近にあると考えている。したがって，村崎 野浮石層（本研究の MKP-II と MIP に相当）の攪乱 も寒冷期に扣ける周氷河現象に基づくと考光てよいであ ろら.Fig. 4 に执いて MKP-II を覆ら褐色火山灰層中 には岩片，亚角砂を含告が，これは火山灰が降下後りリ フラクション作用を受けたことを示唆する。

村崎野浮石層は中川ら（1963）が関東地方に発達する 下末吉段丘に対比した村崎野段丘および赤色風化殼を覆 っている．下末吉段丘和よび東北地方に氺ける赤色風化 凯の形成時期は高海水準期のリス/ウルム間水期と考克 られる（松井·加藤，1962）ので，村崎野浮石層の噴出 は村崎野段丘や赤色風化殼形成後のウルム氷期中である と考えられる。ささらに村崎野浮石を覆ら褐色火山乍層は 北上川上流域に 分布する 西岩手火山起源の渋民火山灰

(3 万年以上前の貲出物) より 女風化と酸性化が進行し ている (Table 1 参照) ことから，ウルム氷期でもより 古い時期の寒冷気候下に村崎野浮石の噴出があったと考 えられる。ょた火山灰層中に観察されるソリフラクショ ン作用はその後の寒冷期の影響を受けたものと推定され る. したがって, 村崎野浮石は約 $4 \sim 7$ 万年前の噴出物 と推定される。これは考古学的資料よりその噴出時期を 数万年ないしそれ以上前と推定した小野・庄子 (1978) の研究と矛盾しない.

な拉, No. 21 断面には前沢火山灰層中に 2 層の赤色風 化を受けた火山灰層をはさんでいる。これは前沢火山灰 がリス/ウルム間水期の温暖期中前後に降灰したことを 推論させる.

\section{（5）黑沢尻火山灰の一次鉱物組成}

No. 47 断面を含导 6 箇所から得られた 26 点の試料に ついて $1 / 8 \sim 1 / 16 \mathrm{~mm}$ 画分の重鉱物含量と一次鉱物組成 を調べた。

Table 1 に No. 47 断面の土培学的性質を, また Table 2 に重鉱物含量と一次鉱物組成を示す。同定した テフラ中の主な重鉱物はシソ輝石，普通輝石，角閃石， 黑雲母括よび磁鉄鉱である. Table 2 によれば，村崎野 浮石層のうち重鉱物含量は MKP-II で著しく高く約 
Table 1 Soil Properties of the No. 47 Profile

\begin{tabular}{|c|c|c|c|c|c|c|c|c|c|c|}
\hline $\begin{array}{l}\text { Locality, } \\
\text { Sample No. }\end{array}$ & $\begin{array}{l}\text { Depth } \\
\text { (cm) }\end{array}$ & Horizon & $\underset{\left(\mathrm{H}_{2} \mathrm{O}\right)}{\mathrm{pH}}$ & $\begin{array}{c}\text { Fine } \\
\text { Sand } \\
(8)\end{array}$ & $\begin{array}{c}\text { earth } \\
\text { Silt } \\
(z)\end{array}$ & 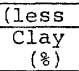 & $\begin{array}{c}\text { than 2.mm) } \\
\begin{array}{c}\text { Humus } \\
\left(\frac{o}{0}\right)\end{array}\end{array}$ & \#Texture & $\begin{array}{l}\text { Soil ** } \\
\text { Color }\end{array}$ & Note $e^{* * *}$ \\
\hline $47-1$ & $0-15$ & $\mathrm{~A}_{11}$ & 5.0 & 10.5 & 25.1 & 35.1 & 25.0 & $\mathrm{HC}$ & $10 Y R 2 / 1$ & MG \\
\hline $47-2$ & $15-45$ & $\mathrm{~A}_{12}$ & 5.1 & 11.6 & 28.1 & 34.4 & 25.0 & $\mathrm{HC}$ & IOYRI/I & FG \\
\hline $47-3$ & $45-65$ & $\mathrm{~A}_{23}$ & 5.0 & 15.4 & 27.4 & 40.8 & 13.8 & $\mathrm{HC}$ & $10 \mathrm{YR} 2 / 2$ & SB \\
\hline $47-4$ & $65-110$ & $\operatorname{IIB}_{\mathrm{b}}$ & 5.3 & 21.5 & 28.4 & 51.0 & 1.5 & $\mathrm{HC}$ & IOYR4.5/6 & B \\
\hline $47-5$ & $110-130$ & $\operatorname{IIC}_{\mathrm{b}}$ & 5.5 & - & - & - & - & - & $\begin{array}{l}\text { 10YR4.5/6 } \\
\times 10 Y R 7 / 8\end{array}$ & rich in $M K P-I I$ \\
\hline $47-6$ & $130-185$ & $\operatorname{IIIB}_{b}$ & 5.5 & 20.9 & 28.2 & 48.9 & - & $\mathrm{HC}$ & $7.5 Y R 5 / 8$ & \\
\hline $47-7$ & $185-220$ & $\operatorname{IIIC}_{1 \mathrm{~b}}$ & - & - & - & - & - & - & $\begin{array}{l}\text { 10YR7/8 } \\
\times 10 Y R 4.5 / 6\end{array}$ & MIP, clay deposits \\
\hline $47-8$ & $220-330$ & $\operatorname{IIIC}_{2 b}$ & - & - & - & - & - & - & $7.5 Y R 7 / 8$ & MIP, $\begin{array}{l}\text { rich in } \\
\text { gel film }\end{array}$ \\
\hline $47-9$ & $330-358$ & $\operatorname{IIIC}_{3 b}$ & - & - & - & - & - & - & $2.5 \times 7 / 5$ & SVA-1, \\
\hline $47-10$ & $358-$ & $I V B_{b}$ & 5.6 & 20.1 & 23.2 & 56.3 & $=$ & $\mathrm{HC}$ & $10 \mathrm{YR} 4.5 / 6$ & MVA \\
\hline
\end{tabular}

\# Sand, 2-0.02 mm; Silt, 0.02-0.002 mm; Clay, less than $0.002 \mathrm{~mm}$; Humus, Tyurin's method.

* Isss method, HC, Heavy Clay. ** Munsell soil color for the wet soil.

*** MG, medium granular; FG, fine granular; SB, subblocky; B; blocky.

47-1 to 47-9: the Kurosawajiri Volcanic Ash, 47-10: the Maesawa Volcanic Ash.

90\% である. MKP-II の上下に存在する MKP-I と MKP-III のそれは約 50〜65\% である。一方，MIP 拉 よびその下位にある固結火山灰層の重鉱物含量は MKP 一II に比べてかなり低く，それぞれ約 40〜60\%，約 20 〜 40\% である。

重鉱物組成は MKP-II では磁鉄鉱>シソ輝石>普通 輝石であるが, MKP-I～～MKP-III はシソ輝石>磁鉄 鉱>普通輝石である. MKP - I 〜III はいずれも角閃石 と黒雲母を汪とんどあるいは全く含んでいない，一方， MIP の重鉱物組成はシソ輝石 $>$ 磁鉄鉱 $\geq$ 普通輝石 $>$ 角 閃石であり，微量の黒雲母を含んでいる. 固結火山灰層 のそれは MIP に類似するがやや黒雲母含量が高いな 扮, テフラ中に微量に存在する黒雲母は噴火の際混入し た基岩である花崗閃緑岩岩片の風化物に由来すると考え られる。

軽鉱物画分（s. g. <2.90） 斜長石と石英を主成分と し，微量の黒雲母が混在している.MKP-II と MKP-III は石英を微量にしか含まないが，MKP-I の石英含量は かなり高い，一方，胆沢浮石層の石英含量は MIP で中 程度であり，SVA-1〜3 ではやや高い。

以上の結果を総合すると村崎野浮石層の一次鉱物組成 は重鉱物のシソ輝石，普通輝石，角閃石祘よび磁鉄鉱之 軽鉱物の斜長石，石英を主成分とすることがわかる，乙 かし，各降下単位ごとに重鉱物含量と一次鉱物組成は少 しずつ異って扣り,MKP-II と MIPを比較すると重鉱 物含量执よ゙角閃石と石英の含量に大きな差が見られ
る。

つぎに No. 47 断面に拉ける黒沢尻火山灰の各層序に つて重鉱物含量と重鉱物組成を比較すると, MKP-II に富む第 5 層を除くと第 1 層〜第 6 層子での火山灰層の 重鉱物含量は 11〜23\%であり，いずれも磁鉄鉱，普通 輝石，シソ輝石，角閃石を含んでいる。また第 $1 \sim 3$ 層 之第 4，6層の火山灰層の磁鉄鉱含量に多少の違いがあ るが，これには火山灰の風化度の違いが影響していると 思われる.したがって，重鉱物組成から第 $1 \sim 3$ 層の火 山灰と第 $4 ， 6$ 層の火山灰の起源を区別することは困難 である、第 5 層は MKP-II に富む褐色火山帙層である ため MKP-II の性質を反映して重鉱物含量が著しく高 い. 第 7，8層 (MIP) と第 9 層 (SVA-1) は前述のと 特りシソ輝石 $>$ 磁鉄鉱>普通輝石>角閃石である。黑沢 尼火山灰の下部にある前沢火山灰層（第 10 層）は重鉱 物含量が著しく低く，重鉱物組成は不透明鉱物（主に磁 鉄鉱）が約 $90 \%$ を占め少量のシソ輝石，普通輝石之微 量の角閃石を伴ら.

な特，比較のため夏油川流域の上夏油(No. 18) に特い て MKP-II の上部にある二次堆積物の茶褐色火山灰質 凝灰層の重鉱物含量之一次鉱物組成8 Table 2 K示寸. No. 18-1 の重鉙物含量之重鉱物組成は MIP 類似乙 ているが，軽鉱物中の石英含量は著しく異なっている.

（6）強磁性鉱物の化学組成と V-Zn ベルトによる テフラの岩質判定

庄子ら (1974) 特よび SHOJi et al. (1975) は日本の 
Table 2 The Primary Mineral Composition of the Kurosawajiri

Volcanic Ash and Secondary Domposits

\begin{tabular}{|c|c|c|c|c|c|c|c|c|c|c|}
\hline $\begin{array}{l}\text { Locality, } \\
\text { Sample No. }\end{array}$ & $\begin{array}{l}\text { Tephra \& } \\
\text { Deposit: }\end{array}$ & $\begin{array}{l}\text { Heavy } \# \\
\text { Minerals } \\
(8)\end{array}$ & $\begin{array}{l}\text { Hear } \\
\text { Ho } \\
(8) \\
\end{array}$ & $\begin{array}{c}\text { vy M } \\
\text { Hy } \\
(8)\end{array}$ & $\begin{array}{c}\text { iner: } \\
\mathrm{Au} \\
(\mathrm{g}) \\
\end{array}$ & $\begin{array}{l}\mathrm{al} \mathrm{C} \\
\mathrm{Bt} \\
\left(\frac{8}{8}\right) \\
\end{array}$ & $\begin{array}{c}\text { Compos } \\
M g \\
(8)\end{array}$ & $\begin{array}{l}\text { sition }^{*} \\
\text { Uk } \\
(8)\end{array}$ & $\begin{array}{l}* \text { Light } * * \\
\text { Mineral } \\
\text { Composition }\end{array}$ & $(8)^{* * *}$ \\
\hline $25-1$ & $\mathrm{~Gb}-2$ & 56 & 11 & 38 & 11 & 0 & 37 & 3 & $\mathrm{Qz} \gg \mathrm{PI}>\mathrm{Bt}$ & 50 \\
\hline $25-2$ & MIP & 43 & 6 & 41 & 21 & $\operatorname{tr}$ & 28 & 4 & $\mathrm{PI} \gg \mathrm{Qz}>\mathrm{Bt}$ & $=15$ \\
\hline $25-3$ & SVA -2 & 30 & 5 & 39 & 22 & 1 & 31 & 3 & $\mathrm{PI}>\mathrm{Qz}>\mathrm{Bt}$ & $=26$ \\
\hline $25-4$ & $S V A-3$ & 22 & 5 & 36 & 18 & 2 & 35 & 4 & $\mathrm{Qz} \geq \mathrm{Pl}>\mathrm{Bt}$ & $=50$ \\
\hline $47-1$ & ash & 14 & 6 & 35 & 20 & 0 & 35 & 4 & $\mathrm{Qz} \geq \mathrm{Pl}$ & 46 \\
\hline $47-2$ & ash & 11 & 5 & 41 & 17 & 0 & 31 & 6 & $\mathrm{Qz}>\mathrm{Pl}$ & 31 \\
\hline $47-3$ & ash & 17 & 7 & 43 & 13 & 0 & 33 & 4 & $\mathrm{Qz} \gg \mathrm{PI}$ & 44 \\
\hline $47-4$ & ash & 19 & 5 & 24 & 7 & 0 & 59 & 5 & $\mathrm{Qz} \gg \mathrm{Pl}$ & 42 \\
\hline $47-5$ & $\left\{\begin{array}{l}\text { ash, } \\
\text { MKP-II }\end{array}\right.$ & 70 & 3 & 36 & 22 & 0 & 35 & 4 & $\mathrm{PI} \gg \mathrm{Qz}$ & 21 \\
\hline $47-6$ & ash & 23 & 9 & 22 & 10 & 0 & 55 & 4 & $\mathrm{Qz} \gg \mathrm{Pl}$ & 50 \\
\hline $47-7$ & $\left\{\begin{array}{l}\text { MIP, } \\
\text { ash }\end{array}\right.$ & 61 & 5 & 36 & 22 & 0 & 34 & 3 & $\mathrm{Pl}>\mathrm{Qz}$ & 22 \\
\hline $47-8$ & MIP & 42 & 3 & 38 & 22 & $\operatorname{tr}$ & 34 & 3 & $\mathrm{Pl} \gg \mathrm{Qz}$ & 16 \\
\hline $47-9$ & $S V A-1$ & 34 & 4 & 39 & 21 & 1 & 33 & 2 & $\mathrm{PI} \gg \mathrm{Qz}$ & 21 \\
\hline $47-10^{\# \#}$ & ash & 11 & 1 & 6 & 5 & 0 & 88 & 0 & $\mathrm{Qz} \gg \mathrm{PI}$ & 45 \\
\hline $49-1$ & MIP & 37 & 3 & 46 & 24 & $\operatorname{tr}$ & 23 & 4 & $\mathrm{PI} \gg \mathrm{Qz}$ & 10 \\
\hline $49-2$ & SVA-I & 37 & 4 & 43 & 19 & $\operatorname{tr}$ & 31 & 3 & $\mathrm{PI}>\mathrm{Qz}$ & 14 \\
\hline $49-3$ & $S V A-2$ & 23 & 5 & 41 & 13 & 1 & 35 & 5 & $\mathrm{PI} Z \mathrm{Qz}>\mathrm{Bt}$ & $=25$ \\
\hline $49-4$ & SVA-3 & 20 & 5 & 40 & 16 & 1 & 34 & 4 & $\mathrm{PI} \geq \mathrm{Qz}>\mathrm{Bt}$ & $=28$ \\
\hline $59-1$ & $M K P-I I$ & 90 & 0 & 25 & 14 & 0 & 59 & 2 & $\mathrm{PI} \gg \mathrm{Qz}$ & 2 \\
\hline $59-2$ & MKP-III & 64 & 0 & 46 & 22 & 0 & 30 & 2 & $\mathrm{P} 1 \gg \mathrm{Qz}$ & 3 \\
\hline $117-1$ & $M K P-I$ & 48 & 1 & 48 & 21 & tr & 26 & 4 & $\mathrm{Qz} \geq \mathrm{PI}>\mathrm{Bt}$ & $=38$ \\
\hline $117-2$ & $\mathrm{~Gb}-1$ & 33 & 0 & 50 & 14 & 0 & 33 & 3 & $\mathrm{Qz} \gg \mathrm{PI}$ & 50 \\
\hline $117-3$ & MKP-II & 83 & 0 & 41 & 12 & 0 & 44 & 3 & $\mathrm{PI} \gg \mathrm{Qz}$ & 2 \\
\hline $18-1$ & $\begin{array}{l}\text { secondary } \\
\text { deposits }\end{array}$ & $\begin{array}{l}Y \\
49\end{array}$ & 2 & 40 & 24 & 0 & 31 & 3 & $\mathrm{QZ} \geq \mathrm{PI}$ & 39 \\
\hline $18-2$ & $\begin{array}{l}\text { secondary } \\
\text { deposits }\end{array}$ & Y 19 & 6 & 19 & 4 & 0 & 69 & 2 & $\mathrm{PI} \gg \mathrm{Qz}$ & 25 \\
\hline $18-3$ & MKP-II & 88 & 0 & 30 & 20 & 0 & 46 & 4 & $\mathrm{Pl} \gg \mathrm{Qz}$ & 2 \\
\hline
\end{tabular}

\# Weight percentage in 1/8-1/16 mm fractions (s.g. more than 2.90)

* Particle percentage, Ho; Hornblende, Hy; Hypersthene, Au; Augite,

Bt; Biotite, Mg; Magnetite, Uk; Unknown

**s.g. less than 2.90, 1/8-1/16 mm fractions, Qz; Quartz, Pl; Plagioclase

*** Weight percentage: in 1/8-1/16 mm fnactions (s.g. less than 2.90)

\#\# the Maesawa Volcanic Ash. For legend see Fig. 1 and Table 1.

各地から採集した多数の新鮮な火山灰中に含まれる強磁 性鉱物の化学分析を行ない，強磁性鉱物中の微量成分之 噴出物の 起源, 噴出物の化学的性質との 関係を検討し た.この結果強磁性鉱物の微量成分であるVと Zn 含量 が火山灰の岩質と密接な関係にあることを明らかにし，

Fig. 5 に示すよらな強磁性釷物の $\mathrm{V} /(\mathrm{Fe}+\mathrm{Ti})-\mathrm{Zn} /$ $(\mathrm{Fe}+\mathrm{Ti})$ と珪酸含量による火山灰の化学的分類との関 係 (V-Znベルト) を示した. そして，一般に風化や分 級の影響が大きい場合, 火山扊の全珪酸含量による岩質 決定は困難となるが，この場合でも SHoji et al. (1975) は火山灭中の強磁性鉱物の $\mathrm{V}-\mathrm{Zn}$ 含量によって岩質判 定が可能であることを指摘した. 本研究地域の火山洃は
風化が著しく進行しているのでその岩質判定には強磁性 鉱物の $\mathrm{V}-\mathrm{Zn}$ ベルトの利用が有効と考えられる.

14 箇所の黑沢层火山灰層（前沢火山灰を含む）から採 集した 36 点の試料より分離・精製した強磁性鉣物（主 として磁鉄鉱，チタン鉄鉱なぞ）の化学組成を Table 3 に示吉. 強磁性鉱物の全 $\mathrm{Fe}$ 含量は約 $58 \sim 62 \%, \mathrm{Ti}$ は 約 $4 \sim 6 \%$ の範囲にあり，いずれも比較的よく精製さ れている。また, 微量成分の含量は $\mathrm{Zn}$ 含量がやや高い No. 47 断面の第 1 層〜第 3 層火山灰を除壮ば，Mn は 約 $0.28 \sim 0.34 \%, \mathrm{~V}$ は約 $0.21 \sim 0.28 \%, \mathrm{Zn}$ は約 580 〜50 ppm である. MIP と MKP-I〜IIIの Zn 含量 を比較すると前者の方が後者よりやや高い。しかし，V 
Table 3 Chemical Gomponents of Ferromagnetic Minerals Purified From the Tephra and Secondary Deposits

\begin{tabular}{|c|c|c|c|c|c|c|}
\hline $\begin{array}{l}\text { Locality, } \\
\text { Sample No. }\end{array}$ & $\begin{array}{l}\text { Tephra \& } \\
\text { Deposit }\end{array}$ & $\begin{array}{c}\text { Total Fe } \\
\left(\frac{8}{0}\right)\end{array}$ & $\begin{array}{l}\mathrm{Ti} \\
(\mathrm{i})\end{array}$ & $\begin{array}{c}\mathrm{Mn} \\
(0)\end{array}$ & $\begin{array}{l}\mathrm{V} \\
\left(\frac{8}{0}\right)\end{array}$ & $\begin{array}{l}\mathrm{Zn} \\
(\mathrm{ppm})\end{array}$ \\
\hline 2 & MKP-II & 61.0 & 5.24 & 0.312 & 0.266 & 620 \\
\hline $3-4$ & MKP-II & 61.9 & 5.28 & 0.318 & 0.267 & 663 \\
\hline $18-I$ & $\begin{array}{l}\text { secondary } \\
\text { deposits }\end{array}$ & 62.1 & 4.60 & 0.329 & 0.264 & 626 \\
\hline $18-2$ & $\begin{array}{l}\text { secondary } \\
\text { deposits }\end{array}$ & 63.4 & 5.17 & 0.317 & 0.271 & 683 \\
\hline $18-3$ & MKP-II & 60.5 & 5.21 & 0.313 & 0.272 & 659 \\
\hline $25-2$ & MIP & 60.6 & 4.55 & 0.283 & 0.220 & 724 \\
\hline $25-3$ & SVA-2 & 61.1 & 4.77 & 0.293 & 0.247 & 654 \\
\hline $25-4$ & SVA -3 & 62.3 & 4.29 & 0.305 & 0.265 & 592 \\
\hline $26-2$ & MIP & 60.2 & 4.78 & 0.273 & 0.228 & 700 \\
\hline $26-3$ & SVA-2 & 61.9 & 4.98 & 0.302 & 0.248 & 655 \\
\hline $26-4$ & SVA-3 & 61.9 & 4.27 & 0.302 & 0.238 & 596 \\
\hline $37-1$ & MIP & 60.5 & 4.80 & 0.266 & 0.220 & 710 \\
\hline $37-2$ & SVA-1 & 58.9 & 4.80 & 0.329 & 0.236 & 636 \\
\hline $47-1$ & ash & 58.5 & 6.05 & 0.425 & 0.230 & 1104 \\
\hline $47-2$ & ash & 58.4 & 5.95 & 0.434 & 0.172 & 1116 \\
\hline $47-3$ & ash & 59.4 & 5.25 & 0.390 & 0.213 & 1073 \\
\hline $47-4$ & ash & 59.6 & 5.32 & 0.386 & 0.207 & 875 \\
\hline $47-5$ & $\begin{array}{l}\text { ash, } \\
\text { MKP-II }\end{array}$ & 60.2 & 4.89 & 0.323 & 0.233 & 719 \\
\hline $47-6$ & ash & 61.2 & 4.91 & 0.319 & 0.208 & 722 \\
\hline $47-7$ & MIP, ash & 60.1 & 4.70 & 0.293 & 0.221 & 680 \\
\hline $47-8$ & MIP & 60.2 & 4.70 & 0.298 & 0.227 & 712 \\
\hline $47-9$ & SVA-I & 58.4 & 4.73 & 0.303 & 0.239 & 639 \\
\hline $47-10$ & ash & 59.3 & 4.98 & 0.546 & 0.169 & 771 \\
\hline $49-1$ & MIP & 60.7 & 4.77 & 0.299 & 0.218 & 739 \\
\hline $49-2$ & SVA-I & 62.4 & 4.95 & 0.302 & 0.241 & 678 \\
\hline $49-3$ & $S V A-2$ & 61.9 & 4.69 & 0.308 & 0.245 & 660 \\
\hline $49-4$ & SVA-3 & 61.9 & 4.06 & 0.324 & 0.248 & 586 \\
\hline $59-1$ & MKP-II & 59.2 & 5.21 & 0.309 & 0.278 & 637 \\
\hline $59-2$ & MKP-III & 58.4 & 5.23 & 0.283 & 0.281 & 613 \\
\hline 92 & MIP & 60.1 & 4.84 & 0.301 & 0.225 & 703 \\
\hline 99 & MKP-II & 58.7 & 5.19 & 0.304 & 0.270 & 642 \\
\hline $116-1$ & $M K P-I$ & 57.8 & 4.76 & 0.312 & 0.283 & 595 \\
\hline $117-1$ & MKP-I & 58.8 & 4.74 & 0.278 & 0.272 & 568 \\
\hline $119-10$ & MIP & 61.9 & 5.11 & 0.302 & 0.247 & 748 \\
\hline $119-11$ & SVA -2 & 61.8 & 4.72 & 0.309 & 0.236 & 645 \\
\hline $119-12$ & $S V A-3$ & 58.7 & 4.34 & 0.335 & 0.253 & 579 \\
\hline
\end{tabular}

For legend see Fig. 1 and Table 1 .

は $\mathrm{Zn}$ と逆の傾向を示している.さらに Zn, Mn 含量と

V含量の間には浪ぼ負の関係が認められる.

第 3 表に示した試料について強磁性鉱物の $\mathrm{V} /(\mathbf{F e}+$ Ti) と $\mathrm{Zn} /(\mathrm{Fe}+\mathrm{Ti})$ の関係を Fig. 5 に示す.

北上浮石層 (MKP-I〜III) はいずれも安山岩質であ る. 一方, 胆沢浮石層 (MIP と SVA-1〜3) では MIP がやや石英安山岩質で固結火山灰層 (SVA-1〜3) はいず 机安山岩質である (Fig. 5). そして SVA-3 $\rightarrow$ SVA-
$2 \rightarrow$ SVA-1 $\rightarrow$ MIP と安山岩質から石英安山岩質の方向 一岩質の連続的な変化が認められる.

一方, No. 47 断面の各層序のテフラを重鉣物組成から 区分することは困難であるが，強磁性鉱物の化学組成よ り決定される各層序の岩質は第 1 層〜第 3 層が流紋岩質 であり，石英安山岩～安山岩質の第 4 層以下とは異なっ ている.また，MKP-II に富む褐色火山灰層である第 $\mathbf{5}$ 層の岩質は第 4 層の火山灰層之 MKP-II の中間の岩質 
を示す．第 6 層の火山灰層と第 7,8 層の MIP はいず れも石英安山岩質で，第 9 層の SVA-1 は安山岩質であ る.

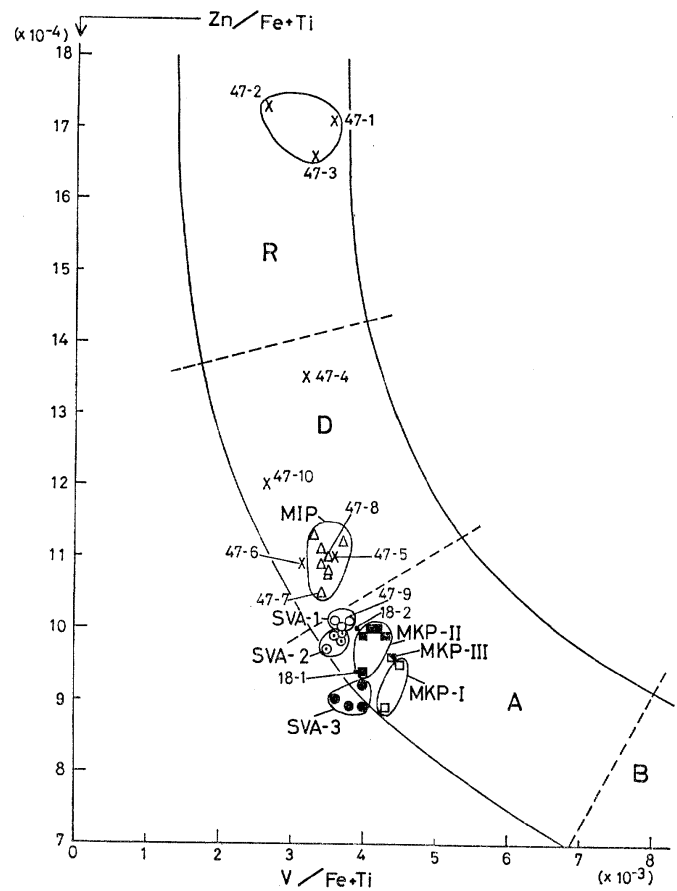

Fig. 5 The Relationships between V-Zn Belt and the Rock Type.

R; Rhyolite, D; Dacite, A; Andesite, B; Basaltic Andesite. For legend see Table 3.
この結果は黒沢屑火山灰が石英安山岩〜安山岩質火山 灰より構成される累積性火山灰であるといら小野・庄 子 (1978) の研究結果とほぼ一致している. 小野・庄子 (1978) によれば北上市相去町，六原農場付近を特和ら黒 沢尻火山灰の上部は 5,000 年以内の噴出物之される新期 火山灰によって覆われ，その岩質は石英安山岩とされて いる. 本研究に和いて焼石岳山頂付近から天竺山北麓, 経塚山付近にかけて流絞岩質の灰白色〜淡黄褐色浮石層 を伴ら新期火山灰の存在を確認した(井上・未発表). 未 た，小野・庄子 (1978) が研究した調㚗地点の南方約 10 $\mathrm{km}$ に位置する金ヶ猗町女夫坂付近の No. 47 断面では 黑沢尻火山兏層の上部の腐植に富も火山乍層も流紋岩質 である (Fig. 5). 本火山灰層はいずれも Table 1 に示 すよらに土性は重埴土で風化と酸性化が著しく進行し ている。したがって，No. 47 断面は小野・庄子 (1978) が研究した調查地点と多少異なっているが，いわゆる黒 沢居火山灰層が噴出時期と岩質の異なる焼石火山起源の 噴出物のみから構成される景積性火山灰ではなく，場所 によっては（特に金ケ崎以南で）暴なった噴出源（たと えば栗駒火山）由来の噴出物が黒沢㞔火山灰の上部に混 大されている可能性を示している。これはNo. 101 断面 や東山町小沼付近に扣いて，黑沢尻火山灭の上部に 2 層 の石英に富导石英安山岩〜流紋岩質浮石層が存在するこ とからも十分考学られる。

なお，第 10 層の前沢火山扊は石英安山岩質である. また夏油川流域に扣いて MKP-II の上部にめる二次堆 積物の火山灭質凝灰層は安山岩質であり MIP の岩質之 異なっている.

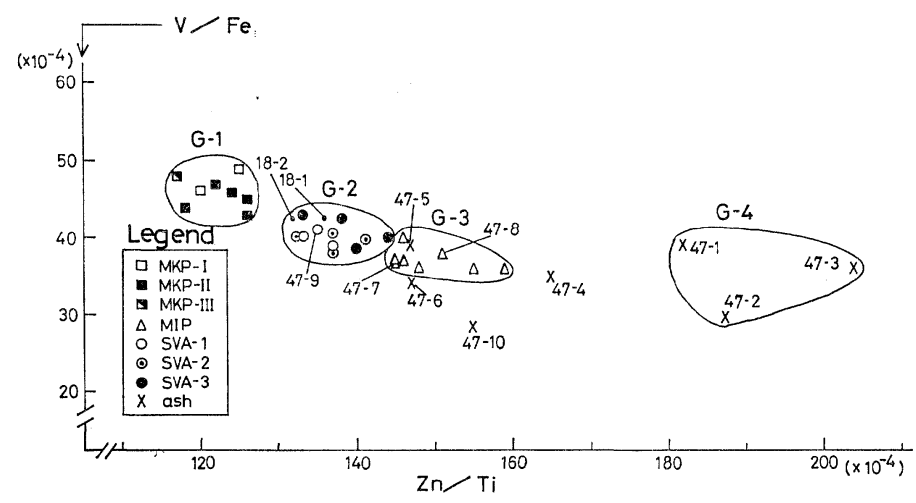

Fig. 6 The Relationships between V-Zn Contents of Ferromagnetic Minerals and the Source Volcano.

G-1; Group 1, G-2; Group 2, G-3; Group 3, G-4; Group 4. For legend see Table 3. 
庄子ら (1974) は強磁性鉱物の $\mathrm{V} / \mathrm{Fe}$ と $\mathrm{Zn} / \mathrm{Ti}$ の 間には負の相関があり，同一起源のテフラは互いにまと まりがよく噴出源，噴出時期ごとに区分されることを明 らかにした．そこで Table 3 に示した結果について $\mathrm{V} / \mathrm{Fe}-\mathrm{Zn} / \mathrm{Ti}$ の関係を Fig. 6 亿示す.36 点のテフラ のららいわ和る黒沢尻火山灰層は 4 つのグループに大別 される。すなわち，MKP-I，II招よび吕から構成され る北上浮石層（第 1 グループ）, 金ヶ崎固結火山灰 (第 2 グループ), MIP (第 3 グループ), 拈よび No. 47 断面の 第 1 第 3 層火山灰（第 4 グループ）である. 北上浮石 層と胆沢浮石層（第 1 第 3 グループ）はいずれも分布 の形状からも明らかなよう飞焼石岳を噴出源としている が，噴出時期によって強磁性鉱物の微量成分の含量が降 下物間で少しずつ連続的に変化している (Fig. 6). これ に対し，流紋岩質の第 4 グループは第 1 〜第 3 グループ と明確に区別される。これはすでに述べたよらに黒沢尻 火山灰の上部に噴出源の異なるテフラが混入されている ことを裏付ける。また，強磁性鉱物の化学組成はテフラ の起源・岩質の判定に有効であることを示唆している.

\section{IV. ま と め}

北上川中流域飞発達する村崎野 (胆沢) 段丘恃下部に 村崎野浮石層を伴う黒沢㞔火山灰によって覆われる. 村崎野浮石層は分布・釷物組成, 岩質怙よび eruptive cycle の異なる 2 つの浮石層，すなわら北上浮石層之胆 沢浮石層に区分され，いずれも焼石火山起源の噴出物で ある. 北上浮石層は 3 つ降下単位（MKP-I～III）よ り構成される. そのらち MKP-II は最も層厚が厚く焼 石岳の北東方向に分布し, 北上山地南部の大部分を覆っ ている。また，胆沢浮石層は 4 つの降下単位 (MIP と SVA-1３）より構成される.MIP は焼石岳東南東方向 に広範团に分布し北上山地にまで達するが, MIP の下部 にある 3 つの固結砂状火山灰層は焼石岳南東〜東方に比 較的狭い範围飞分布している.

MIP の噴出時期は MKP-I 〜 III の爷れよりも早く, 両者の間には若干の時間的間隙がある。また MIP 特よ びMKP-II と上部の火山灰層との境界部にインボリュ ーションが各地で観察される.さらに段丘地形や赤色風 化款と村崎野浮石層との層序学的関係, 浮石層にみられ る化石周氷河現象和よび火山灰の風化度から，村崎野浮 石層の噴出時期はウルム氷期前半（約 $4 \sim 7$ 万年前）と 推定される.

MKP-I 〜III の 重釷物組成は磁鉄鉱 Zシソ輝石>普 通輝石でその重鉱物含量注約 50～90\% である。一方，
MIP と SVA-1 3 はシソ輝石 $\geq$ 磁鉄鉱>普通輝石 >角 閃石でその重鉱物含量は約 20〜60\% である.また MIP と SVA-1〜3 梳石英を含むが, MKP-II はこれを活と んど含んでいない.

テフラより分離・精製した強磁性鉱物の化学組成よ り, MIP 蛙石英安山岩質, MKP-I〜III 和よび SVA1〜3 は安山岩質と判定される。末た黒沢尻火山灰の大 部分は焼石火山起源であり，その岩質は石英安山岩質〜 安山岩質であるが，場所によってはとの上部に異なった 噴出源（扔朰らく栗駒火山）由来の流紋岩質火山灰が混 入している.

最後に現地調查にめたり，岩手県農業試験場の佐々木 信夫氏には大変特世話になった。ここに記して謝意を表 する.

\section{引用交献}

Cradwick, P. D. G., Farmer, V. G., Russell, J. D., Masson, G. R., Wada, K., and Yoshinaga, N. (1972) Imogolite, a hydrated aluminum silicate of tubular structure. Nature Physical Sci., 240, p. 187189.

遠藤泉二 (1977) 北上川上流部の化石周永河現像. 地理 学会予稿集, 12, p. 22-23.

Henmi, T. and WadA, K. (1974) Surface acidity of imogolite and allophane. Clay Minerals, 10, p. 231245.

井上克弘 ·吉田 稔 (1976) 胆沢扇状地段丘面の累積性 火山灰土の粘士鉱物組成．岩手大農報， 13， p. 19 46.

井上克弘・金子和已・吉田 稔 (1977) 岩手山麓の火山 灰層にみら和る化石周水河現象とその層序. 土肥学会 要旨集, 23, p. 123.

井上克弘（1979）北上川上流域に打ける後期更新世の周 氷河現象之火山灰層序. 第四紀学会要旨集, 8, p. 11 .

INouE, K. (1980) Stratigraphy, distribution, mineralogy, and geochemistry of Late Quaternary tephras erupted from the Akita-Komagatake Volcano, northeastern Japan. Soil Sci. Plant Nutr., 26, p. 43-61. Inoue, K. and YoshidA, M. (1980) Stratigraphy, distribution, mineralogy, and geochemistry of Late Quaternary tephras erupted from the Iwate and Akita-Yakeyama Volcanoes, northeastern Japan. Soil Sci. Plant Nutr., 26, p. 149-166.

菅野一郎・桑野幸男・本乼吉男 (1960) 軽石層中のグル 状皮膜物質の粘土鉱物．粘土科学の進歩，2, p. 355365 , 技報堂.

国土調查（1963）土地分類 基本調查「水沢」，経済企画 㡯.

国土調查 (1970) 土地分類 基本調查「人首」「遠野」, （1971）「大迫」，(1973)「陸中大原」，(1975)「花巻」 「北上」, 岩手県. 
松井 健 - 加藤芳朗 (1962) 日本の赤色土壤の生成時期, 生成環境に関する三，三の考察. 第四紀研究， 2, p. $161-179$.

Mehra, O. P., and Jackson, M. L. (1960) Iron oxide removal from soils and clays by a dithionite-citrate system buffered with sodium bicarbonate. Clays Clay Miner., 7, p. 317-327.

Mryauahi, N. and Aomine, S. (1966) Mineralogy of gel-like substance in the pumice bed in Kanuma and Kitakami districts. Soil Sci. Plant Nutr., 12, p. $19-22$.

村山磐 (1978) 日本の火山（I） 314 p. 大明堂. p. $234-237$.

長友由隆・斎藤交次 (1971) X 線回折法による火山灰土 壤微砂の一次鉱物の同定. 定量. 土肥学会要旨集, 17 , p. 40 .

中川久夫 ·岩井淳一 ·大池昭二 . 小野寺信吾 · 森由紀 子・ 木下 尚. 竹内貞子. 石田环二 (1963) 北上川中 流沿岸の第四系および地形——北上川流域の第四紀地 史 ( 2 ) 一一地質雑，69，p. 219-227.

中川久夫 - 中馬教允 - 石田环二 - 松山 力 . 七崎 修 . 生出慶司 · 大池昭二 ・高橋 一 (1972) 十和田火山発 達史概要. 岩井淳一教授記念論文集, p. 7-17.

大池昭二(1972) 十和田火山東麓に拈ける完新世テフラ の編年. 第四紀研究, 11, p. 228-235.

小野剛志 - 庄子貞雄 (1978) 岩手県北上市付近の火山灰 土壤の生成について, 第 2 報 母材と土壤生成. 第四 紀研究, 17, p. 15-23.

塩入松三郎 (1935) 攀土質土壤の粘土分の三三膠質化学 的研究, 日本学術協会報告, 10, p.694-699.

庄子貞雄 · 小林進介・増井淳一 (1974) 火山灰中の強磁 性鉱物の化学組成と噴出源との関係について, 岩鉱 誌, 69, p. 110-120.

Shoji, S., Kobayashi, S., Yamada, I., and Masui,
J-I. (1975) Relationships between the geochemistry of ferromagnetic component and the chemical properties of air-born pyroclastic materials. J. Japan. Assoc. Min. Petr. Econ. Geol., 70, p. 12-24.

鈴木秀夫 (1962) 低位周氷河現象の南限と最終氷期の気 候区界. 地理学評論, 35, p. 67-76.

Wada, K. and Matsubara, I. (1968) Differential formation of allophane, "imogolite" and gibbsite in the Kitakami pumice bed. Trans. 9th Int. Cong. Soil Sci., 3, p. 123-131.

WAdA, K. and Henmi, T. (1972) Characterization of micropores of imogolite by measuring retention of quatenary ammonium chlorides and water. Clay Sci., 4, p. 127-136.

WAdA, S-I. and WAdA, K. (1977) Density and structure of allophane. Clay Minerals, 12, p. 289-298.

若生達夫（1964）東北日本における地形面と赤色風化款 との関係. 第四紀研究，3，p. 197-211.

Yoshinaga, N. and Aomine, S. (1962) Imogolite in some ando soils. Soil Sci. Plant Nutr., 8, p. 114 121.

Yoshinaga, N., Nakai, M., and Yamaguchi, M. (1973) Unusual accumulation of gibbsite and halloysite in the Kitakami pumice bed, with a note on their genessis. Clay Sci., 4, p. 155-165.

〔追記】投稿後，土肥誌 51，339-341（1980）に“北 上軽石の分布とその性質”（小野剛志・庄子貞雄）方”発 表された。本報告では和賀町上夏油付近に火厒流堆積物 の存在が指摘されている。したがって，中川ら（1963） による「夏油川流域において若い扇状地性磁層下に埋没 した浮石層の上半部」はこの火砕流堆積物である可能性 がある。 